\title{
PENINGKATAN KUALITAS MIE MELALUI MODIFIKASI TEPUNG KEDELAI MENDUKUNG PEMANFAATAN BAHAN PANGAN LOKAL
}

\author{
Suriany, Wanti Dewayani, Idaryani, Reswita, Farida Arief, dan Warda Halil \\ Balai Pengkajian Teknologi Pertanian (BPTP) Sulawesi Selatan \\ Jl. Perintis Kemerdekaan Km. 17.5, Sudiang, Makassar \\ e-mail: suriany1965@gmail.com
}

Received: 12 Oktober 2020; Accepted: 29 November 2020; Published: 25 Desember 2020

\begin{abstract}
ABSTRAK
Peningkatan kualitas mie melalui modofikasi tepung kedelai mendukung pemanfaatan bahan pangan lokal bertujuan (1) untuk meningkatkan kualitas mie, (2) mendapatkan proporsi tepung kedelai yang tepat dalam pembuatan mie, dan (3) untuk meningkatkan pemnfaatan pangan local. Penelitian dilaksanakan mulai Bulan Januari sampai Desember 2019. Rancangan percobaan yang digunakan yaitu rancangan acak lengkap 2 faktor. Faktor pertama adalah penggunaan tepung kedelai dari 3 varietas yaitu Detap 1, Deja 1 dan Dena, sedangkan factor kedua adalah proporsi penggunaan tepung kedelai yaitu $0 \% ; 20 \%$; $40 \%$ dan $50 \%$. Setiap perlakuan diulang 3 kali. Data yang diamati meliputi sifat fisik dan kimia produk serta uji organoleptic untuk mengetahui tingkat penerimaan konsumen. Hasil penelitian menunjukkan bahwa Perlakuan dengan substitusi tepung kedelai sebesar 20-40\% adonan dapat dicetak menjadi mie dengan kualitas baik. Perlakuan dengan substitusi $20 \%$ tepung kedelai memberi skore tertinggi dan disenangi panelis.
\end{abstract}

\section{Kata Kunci: Kualitas mie, tepung kedelai, pangan lokal}

\begin{abstract}
Improving the quality of noodles through modification of soybean flour for the use of local foodstuffs aims (1) to improve the quality of the noodles, (2) to get the right proportion of flour in making noodles, and (3) to increase the utilization of local food. The study was conducted from January to December 2019. The experimental design used randomized 2 factors. The first factor is the use of soy flour from 3 varieties, namely Detap 1, Deja 1 and Dena, while the second factor is the use of soy flour, namely 0\%; 20\%; 40\% and 50\%. Each treatment was repeated 3 times. The data observed included physical and chemical properties of the product as well as organoleptic tests to determine the level of consumer acceptance. The results showed that the treatment with soy flour substitution of 20-40\% dough can be molded into noodles with good quality. The treatment with a substitution of $20 \%$ soybean flour gave the highest score and was favored by the panelists.
\end{abstract}

Keywords: Quality of noodles, soy flour, local food

\section{PENDAHULUAN}

Diversifikasi pangan yaitu upaya menganekaragamkan jenis pangan yang dikonsumsi, mencakup pangan sumber energi dan zat gizi, sehingga memenuhi kebutuhan akan pangan dan gizi serta sesuai dengan kecukupan baik ditinjau dari kuantitas maupun kualitasnya.

Salah satu penyebab kerawanan pangan adalah ketergantungan masyarakat pada salah satu pangan pokok saja, yaitu beras. Sekitar 95\% penduduk Indonesia menggantungkan dirinya kepada beras sebagai makanan pokok (Nurmala dan Irawan, 2007). Namun peran beras saat ini diimbangi oleh tepung terigu. Saat ini, konsumsi akan tepung terigu sangat tinggi sebesar 24 kilogram per kapita per tahun pada tahun 2017. Tingginya konsumsi makanan berbahan dasar tepung terigu di Indonesia dikarenakan terjadinya perubahan selera masyarakat yang lebih menyukai

Diterbitkan Oleh, 
makanan berbahan dasar terigu. Untuk pengadaan tepung terigu di Indonesia sangat tergantung pada impor, karena Indonesia bukan negara penghasil gandum sebagai bahan baku tepung terigu.

Sesuai dengan Undang Undang No. 7 tahun 1996, Peraturan Pemerintah (PP) No. 68 tahun 2002 dan Peraturan presiden No. 22 tahun 2009, salah satu jalan keluar dari jurang kerawanan pangan tersebut adalah dengan mewujudkan diversifikasi pangan melalui pengembangan pangan alternatif berbasis sumberdaya lokal.

Usaha untuk mengurangi konsumsi tepung terigu terus digalakkan disamping mencari alternatif pengganti dari bahan baku lainnya, juga dengan mengusahakan tepung lain sebagai tepung campuran (tepung komposit), yaitu suatu bentuk campuran antara tepung dengan beberapa jenis tepung dari bahan lain.

Kacang kedelai termasuk komoditas tanaman pangan yang memiliki peran strategis dalam ketahanan dan kedaulatan pangan nasional, kecukupan gizi penduduk, dan merupakan bahan baku industri olahan pangan. Kedelai termasuk salah satu jenis kacang-kacangan yang mempunyai nilai gizi cukup tinggi dan kaya senyawa aktif yang memiliki efek positif bagi tubuh manusia (Theradiodid.wordpress.com). Diantara jenis kacang-kacangan, kedelai merupakan sumber protein (35 - 45\%), lemak (18 - 23\%), karbohidrat (12 - 30\%), air (7\%), vitamin, mineral, dan serat yang paling baik. Bahkan pada varietas unggul kadar proteinnya dapat mencapai $40-43 \%$.

Kacang kedelai dapat diolah untuk menghasilkan berbagai produk yang sangat dibutuhkan bagi kehidupan manusia, yaitu sebagai produk pangan, farmasi (obat-obatan), aplikasi dalam bidang industri, dan sebagai pakan. Produk pangan olahan kacang kedelai yang utama dan populer dikalangan masyarakat Indonsia adalah produk fermentasi seperti tempe, kecap, tauco dan produk non fermentasi seperti tepung kedelai, tahu, daging tiruan, dan susu.

Tepung kedelai merupakan salah satu produk olahan setengah jadi dari kedelai dengan cara dikeringkan kemudian dihaluskan dan diayak sampai diperoleh tepung kedelai yang halus. Tepung kedelai mengandung protein, karbohidrat, lemak, kalsium, fosfor, dan zat besi. Selain itu di dalam tepung kacang kedelai mengandung vitamin
A, vitamin B1, dan vitamin C (Cahyadi, 2007). Tepung kedelai mempunyai kandungan protein tinggi yaitu sebesar 43,8\%.

Mie merupakan produk pangan yang dibuat dari adonan terigu atau tepung lainnya sebagai bahan utama dengan atau tanpa penambahan bahan tambahan lainnya. Dalam upaya diversifikasi pangan, mie dapat dikategorikan sebagai salah satu produk substitusi karena dapat berfungsi sebagai bahan pangan pokok. Menurut Juniawati (2003), mie merupakan produk pangan yang sering dikonsumsi oleh sebagai besar konsumen baik sebagai sarapan maupun sebagai makanan selingan baik dikalangan anak anak maupun orang dewasa.

Produk mie saat ini telah mengalami perkembangan dengan variasi campuran antara terigu sebagai bahan baku utama dengan bahanbahan lain yang dapat meningkatkan kandungan gizi mie tersebut. Tepung kedelai merupakan tepung yang kaya akan gizi yang dapat ditambahkan dalam proses pembuatannya. Oleh karena itu perlu dilakukan penelitian dengan memanfaatkan tepung kedelai dari beberapa jenis varietas sebagai bahan substitusi dalam membuat mie kedelai bergizi.

\section{METODE PENELITIAN}

Penelitian dilaksanakan pada Bulan January sampai dengan Desember 2019. Ada tiga tahapan kegiatan yang terdiri dari 1) Pembuatan mie dilaksanakan di Laboratorium Pascapanen Balai Pengkajian Teknologi Pertanian (BPTP) Sulawesi Selatan, 2) Analisis proksimat dilaksanakan di Laboratorium Universitas Hasanuddin dan 3) Sosialisasi produk dilaksanakan didaerah sentra pengembangan kedelai Kelurahan Tancung, Kecamatan Tanasitolo, Kabupaten Wajo.

Bahan yang digunakan dalam pembuatan mie adalah tepung kedelai yang terdiri dari 3 jenis varietas, tepung terigu, tepung tapioka, telur, minyak, dan garam. Adapun alat yang digunakan adalah ayakan, penggilingan tepung, kompor, timbangan analitik, dan alat alat laboratorium lainnya.

Penelitian ini menggunakan rancangan acak lengkap 2 faktor, yaitu faktor pertama adalah penggunaan tepung kedelai dari 3 varietas

Diterbitkan Oleh, 
yaitu Detap 1, Deja 1 dan Dena, sedangkan factor kedua adalah substitusi $\mathrm{r}$ penggunaan tepung kedelai yaitu 0\%; 20\%; 40\% dan 50\%. Masingmasing perlakuan diulang sebanyak 3 kali. Uji organoleptik dilakukan terhadap 30 orang panelis. Adapun parameter yang diamati terdiri dari tekstur, warna, aroma dan rasa. Skor penilaian terdiri dari $1=$ sangat tidak suka, $2=$ tidak suka, $3=$ agak suka, $4=$ suka, $5=$ sangat suka.

Karakteristik mie kedelai yang diamati adalah sifat fisik yang meliputi warna dan bentukan mie dihasilkan. Sementara sifat kimia yang diamati meliputi analisis proksimat serta uji organoleptik. Data hasil pengamatan dianalisis sidik ragam dengan menggunakan ANOVA.

\section{HASIL DAN PEMBAHASAN}

\section{Karakteristik Sifat Fisik Mie Kedelai}

Mie adalah makanan alternatif pengganti beras yang banyak dikonsumsi masyarakat. adonan tipis dan panjang yang telah digulung, dikeringkan kemudian dimasak dalam air mendidih. Mie basah yang baik mempunyai ciri-ciri sebagai berikut berwarna putih atau kuning, tekstur agak kenyal dan tidak mudah putus (Astawan, 1999). Tabel 1 memperlihatkan warna dan bentukan mie basah pada berbagai perlakuan.

Tabel 1. Karakteristik sifat fisik mie kedelai

\begin{tabular}{lll}
\hline Perlakuan & \multicolumn{1}{c}{ Warna } & \multicolumn{1}{c}{ Bentukan Mie } \\
\hline S1 Var. A (100\%:0\%) & Putih & Dapat dicetak dengan baik \\
S2 Var.A $(80 \%: 20 \%)$ & Putih kekuningan & Dapat dicetak dengan baik \\
S3 Var.A (60\%: $40 \%)$ & Putih kekuningan & Dapat dicetak dengan baik \\
S4 Var.A (50\%: 50\%) & Putih kekuningan & Dapat dicetak tapi mudah putus \\
S1 Var. B (100\%: $0 \%)$ & Putih & Dapat dicetak dengan baik \\
S2 Var.B $(80 \%: 20 \%)$ & Putih kekuningan & Dapat dicetak dengan baik \\
S3 Var.B (60\%: $40 \%)$ & Putih kekuningan & Dapat dicetak dengan baik \\
S4 Var.B $(50 \%: 50 \%)$ & Putih kekuningan & Dapat dicetak tapi mudah putus \\
S1 Var. C $(100 \%: 0 \%)$ & Putih & Dapat dicetak dengan baik \\
S2 Var.C $(80 \%: 20 \%)$ & Putih kekuningan & Dapat dicetak dengan baik \\
S3 Var.C $(60 \%: 40 \%)$ & Putih kekuningan & Dapat dicetak dengan baik \\
S4 Var.C $(50 \%: 50 \%)$ & Putih kekuningan & Dapat dicetak tapi mudah putus \\
\hline Keran
\end{tabular}

Keterangan :

$\mathrm{A}=$ Varietas Detap 1

$\mathrm{B}=$ Varietas Deja 1

$\mathrm{C}=$ Varietas Dena

$\mathrm{S} 1=100 \%$ tepung terigu

$\mathrm{S} 2=80 \%$ tepung terigu: $20 \%$ tepung kedelai

$\mathrm{S} 3=60 \%$ tepung terigu: $40 \%$ tepung kedelai

$\mathrm{S} 4=50 \%$ tepung terigu: $50 \%$ tepung kedelai

Penambahan tepung kedelai berpengaruh terhadap warna dari mie yang dihasilkan. Perlakuan tanpa penambahan tepung kedelai, mie yang dihasilkan berwarna putih. Sedangkan perlakuan dengan penambahan tepung kedelai berwarna agak kekuningan. Dalam jurnal Pasca Panen Widaningrum, Widowati dan Soekarto (2005) nilai derajat putih untuk tepung terigu sebesar $87 \%$. Dan hal ini menyebabkan semakin rendahnya proporsi tepung terigu yang digunakan maka nilai derajat putih juga semakin berkurang.

Semua perlakuan dapat dicetak menjadi mie, namun semakin tinggi substitusi tepung kedelai, maka penampilan bentukan mie yang dihasilkan tidak dapat membentuk lembaran mie yang panjang. Perlakuan dengan substitusi tepung kedelai sebesar $20-40 \%$ adonan dapat dicetak menjadi mie dengan baik. Hal ini disebabkan 
karena tepung terigu memiliki kemampuan membentuk gluten. Gluten memiilik sifat viskoelastis, sehingga menyebabkan mie tidak mudah putus pada saat peoses pencetakan (Astawan dalam Millah S dan Gemala Anjani, 2017).

\section{Karakteristik Sifat Kimia Mie}

Mie banyak mengandung karbohidrat, yang banyak menyumbang energi pada tubuh sehingga mie dapat dijadikan sebagai makanan pengganti nasi. Substitusi tepung kedelai dalam pembuatan mie bertujuan untuk meningkatkan kandungan gizi dari mie yang dihasilkan

Mie basah yang baik adalah mie yang secara kimiawi mempunyai nilai kimia yang sesuai dengan persyaratan yang yang ditetapkan oleh SNI 2987-1992, yaitu kadar air maksimal 35\%, kadar protein minimal $3 \%$, dan kadar abu maksimal $3 \%$. Tabel 2 menampilkan kandungan gizi mie kedelai dengan beberapa perlakuan.

Tabel 2. Kandungan gizi mie kedelai dengan beberapa perlakuan

\begin{tabular}{|c|c|c|c|c|c|c|c|c|}
\hline \multirow{2}{*}{ Perlakuan } & \multicolumn{8}{|c|}{ Kandungan Gizi } \\
\hline & \multicolumn{2}{|c|}{ Kadar Air (\%) } & \multicolumn{2}{|c|}{ Kadar Abu (\%) } & \multicolumn{2}{|c|}{ Protein $(\%)$} & \multicolumn{2}{|c|}{ Karbohidrat (\%) } \\
\hline \multicolumn{9}{|l|}{ Varietas } \\
\hline A & 19.06 & $\mathrm{a}$ & 1.65 & $\mathrm{a}$ & 19.24 & a & 50.94 & $\mathrm{~b}$ \\
\hline B & 18.50 & $\mathrm{~b}$ & 1.40 & $\mathrm{~b}$ & 19.49 & $\mathrm{a}$ & 51.65 & $\mathrm{a}$ \\
\hline $\mathrm{C}$ & 18.66 & $\mathrm{~b}$ & 1.37 & $\mathrm{~b}$ & 19.12 & $\mathrm{a}$ & 51.53 & $\mathrm{a}$ \\
\hline \multicolumn{9}{|l|}{ Substitusi } \\
\hline S1 (100\%: 0\%) & 21.33 & $\mathrm{a}$ & 1.03 & $\mathrm{~d}$ & 11.86 & $\mathrm{~d}$ & 62.51 & $\mathrm{a}$ \\
\hline S2 (80\%: 20\%) & 17.12 & $\mathrm{~d}$ & 1.19 & $\mathrm{c}$ & 17.69 & $\mathrm{c}$ & 55.15 & $\mathrm{~b}$ \\
\hline S3 (60\%: 40\%) & 17.82 & $\mathrm{c}$ & 1.70 & $\mathrm{~b}$ & 22.82 & $\mathrm{~b}$ & 46.31 & c \\
\hline S4 (50\%: $50 \%)$ & 18.70 & $\mathrm{~b}$ & 1.97 & $\mathrm{a}$ & 24.77 & $\mathrm{a}$ & 41.51 & $\mathrm{~d}$ \\
\hline \multicolumn{9}{|l|}{ Interaksi } \\
\hline A X S1 & 21.33 & $\mathrm{a}$ & 1.03 & $\mathrm{a}$ & 11.86 & $\mathrm{a}$ & 62.51 & $\mathrm{a}$ \\
\hline A x S2 & 16,15 & $\mathrm{c}$ & 1.46 & $\mathrm{a}$ & 17.66 & $a b$ & 55.31 & $\mathrm{a}$ \\
\hline $\mathrm{A} \times \mathrm{S} 3$ & 18.72 & $\mathrm{a}$ & 1.95 & $\mathrm{a}$ & 22.51 & $\mathrm{~b}$ & 45.67 & $\mathrm{a}$ \\
\hline A x S4 & 20.10 & $\mathrm{a}$ & 2.18 & $\mathrm{a}$ & 24.94 & $\mathrm{a}$ & 40.25 & $\mathrm{c}$ \\
\hline B X S1 & 21.33 & $\mathrm{a}$ & 1.03 & $\mathrm{a}$ & 11.86 & $\mathrm{a}$ & 62.51 & $\mathrm{a}$ \\
\hline B x S2 & 18.22 & $\mathrm{a}$ & 1.04 & $\mathrm{a}$ & 17.30 & $\mathrm{~b}$ & 54.93 & $\mathrm{a}$ \\
\hline $\mathrm{B} \times \mathrm{S} 3$ & 16.82 & $\mathrm{a}$ & 1.62 & $\mathrm{a}$ & 23.38 & $\mathrm{a}$ & 46.60 & $\mathrm{a}$ \\
\hline $\mathrm{B} \times \mathrm{S} 4$ & 17.62 & $\mathrm{c}$ & 1.91 & $\mathrm{a}$ & 25.42 & $\mathrm{a}$ & 42.56 & $\mathrm{a}$ \\
\hline $\mathrm{C} \times \mathrm{S} 1$ & 21.33 & $\mathrm{a}$ & 1.03 & $\mathrm{a}$ & 11.86 & $\mathrm{a}$ & 62.51 & $\mathrm{a}$ \\
\hline $\mathrm{C} \times \mathrm{S} 2$ & 16.99 & $\mathrm{~b}$ & 1.07 & $\mathrm{a}$ & 18.10 & $a b$ & 55.20 & $\mathrm{a}$ \\
\hline $\mathrm{C} \times \mathrm{S} 3$ & 17.91 & $\mathrm{~b}$ & 1.54 & $\mathrm{a}$ & 22.57 & $\mathrm{~b}$ & 46.65 & $\mathrm{a}$ \\
\hline $\mathrm{C} \times \mathrm{S} 4$ & 18.39 & $\mathrm{~b}$ & 1.81 & $\mathrm{a}$ & 23.95 & $\mathrm{~b}$ & 41.73 & $\mathrm{~b}$ \\
\hline
\end{tabular}

Angka-angka pada kolom yang sama yang diikuti huruf yang sama menunjukkan nilai yang tidak berbeda nyata pada taraf uji $5 \%$.

Keterangan:

$\begin{array}{lll}\mathrm{A} & = & \text { Varietas Detap } 1 \\ \mathrm{~B} & = & \text { Varietas Deja } 1 \\ \mathrm{C} & = & \text { Varietas Dena } \\ \mathrm{S} 1 & =100 \% \text { tepung terigu } \\ \mathrm{S} 2 & =80 \% \text { tepung terigu: } 20 \% \text { tepung kedelai } \\ \mathrm{S} 3 & =60 \% \text { tepung terigu: } 40 \% \text { tepung kedelai } \\ \mathrm{S} 4 & =50 \% \text { tepung terigu: } 50 \% \text { tepung kedelai }\end{array}$

Diterbitkan Oleh, 


\section{Kadar air}

Varietas Detap 1 memiliki kadar air lebih tinggi dibanding varietas Deja 1 dan Dena. Hasil analisis statistik menunjukkan bahwa varietas Detap 1 berpengaruh nyata terhadap varietas lainnya, tetapi tidak berpengaruh nyata antar varietas Deja 1 dan Dena dalam pembuatan mie.

Perlakuan dengan menggunakan $100 \%$ tepung terigu atau tanpa substitusi tepung kedelai memiliki kadar air lebih tinggi diantara perlakuan lainnya. Namun dengan adanya substitusi tepung kedelai dalam pembuatan mie menyebabkan kandungan air menurun. Semakin tinggi substitusi tepung kedelai, kadar air semakin meningkat. Proporsi substitusi tepung kedelai berpengaruh nyata antar perlakuan.

Secara umum tidak ada interaksi perlakuan antar varietas dengan substitusi tepung kedelai dalam pembuatan mie, kecuali varietas Dena berpengaruh nyata dengan varietas lainnya. Menurut Gamman dan Sherington (1994), peningkatan kadar air selalu diikuti dengan peningkatan kadar protein. Hal ini disebabkan protein dalam bahan pangan berfungsi sebagai pengikat yang mampu meningkatkan daya ikat air terhadap bahan dan bersifat hidrofobik sehingga membutuhkan air yang besar (Kuswandari, 2012 dalam Prasetya 2018).

Standar mutu kadar air mie basah berdasarkan SNI 01-2987-1992 adalah maksimal $35 \%$. Sedangkan kadar air mie yang diperoleh dari hasil penelitian dengan berbagai proporsi tepung kedelai berkisar $15,82-21,33 \%$, sehingga mie yang dihasilkan memenuhi SNI.

\section{Kadar $a b u$}

Hasil analisis statistik menunjukkan bahwa kandungan kadar abu tertinggi diperoleh pada varietas Detap 1 dan berpengaruh nyata terhadap kedua varietas lainnya, tetapi tidak berpengaruh nyata antar Varietas Deja 1 dan Dena dalam pembuatan mie. Semakin tinggi substitusi penggunaan tepung kedelai pada pembuatan mie, kadar abu semakin tinggi. Kadar abu tertinggi diperoleh pada mie dengan perlakuan proporsi substitusi 50\% tepung kedelai: $50 \%$ tepung terigu.

Tidak ada interaksi perlakuan antar varietas dengan proporsi substitusi tepung kedelai dalam pembuatan mie. Kadar abu tertinggi diperoleh pada varietas Detap 1 dengan proporsi substitusi 50\% tepung kedelai: 50\% tepung terigu. Menurut Sudarmadji, et.al, (1989, bahwa kadar abu tergantung pada jenis bahan, cara pengabuan, waktu dan suhu yang digunakan saat pengeringan. Gozali, M (2015), kadar abu tepung kedelai impor dengan proses perebusan sebesar $4,81 \%$, dan kadar abu tepung terigu 0,25-0,60\% (Astawan, 2008).

Menurut standar mutu (SNI 01-29871992), kadar abu mie basah maksimal sebesar $3 \%$. Produk mie dari substitusi tepung terigu dan tepung kedelai mengandung kadar abu 1,03-1,97 \% lebih rendah dari standar mutu yang ditetapkan sehingga mie basah yang dihasilkan telah memenuhi standar mutu yang ditetapkan (BSN, 1992).

\section{Protein}

Hasil analisis statistik menunjukkan bahwa kandungan protein tidak berpengaruh nyata terhadap varietas dalam pembuatan mie. Kadar protein tertinggi diperoleh pada varietas Deja 1 yaitu $19.49 \%$ dan terendah pada varietas Dena yaitu $19.12 \%$.

Proporsi substitusi tepung kedelai berpengaruh nyata antar perlakuan dan perlakuan dengan proporsi substitusi 50\% tepung kedelai:50 tepung terigu memiliki kandungan protein lebih tinggi diantara perlakuan lainnya. Semakin tinggi penambahan tepung kedelai semakin tinggi kandungan proteinnya.

Secara umum tidak ada interaksi perlakuan antar varietas dan rasio penggunaan tepung terigu dan tepung kedelai. Kadar protein tertinggi yaitu 25,42\% diperoleh pada perlakuan varietas Deja 1 dengan rasio penggunaan 50\% tepung terigu: $50 \%$ tepung kedelai, dan terendah yaitu $11,86 \%$ pada rasio penggunaan 100 tepung terigu. Semakin tinggi tepung terigu ditambahkan, semakin rendah kandungan protein. Munurut Singarimbun et al (2009), peningkatan kadar kadar protein pada mie basah seiring dengan banyaknya tepung kedelai yang ditambahkan pada mie kedelai.

Kadar protein pada mie basah yang dihasilkan dengan substitusi tepung kedelai dan tepung terigu berkisar 11.86 - 25.42\%, kadar protein tersebut telah memenuhi standar mutu mie basah (SNI 01-2987-1992) yaitu minumum 3\%.

Diterbitkan Oleh, 


\section{Karbohidrat}

Hasil analisis statistik menunjukkan bahwa Varietas Detap 1 mengandung karbohidrat tertinggi yaitu $50.94 \%$ berpengaruh nyata terhadap kedua varietas lainnya, tetapi tidak berpengaruh nyata antar varietas Deja 1 dan Dena dalam pembuatan mie.

Sedangkan terhadap proporsi substitusi tepung kedelai berpengaruh nyata antar semua perlakuan. Kandungan karbohidrat tertinggi $62.51 \%$ diperoleh pada perlakuan $100 \%$ tepung terigu atau tanpa tepung kedelai dan terendah $17.12 \%$ pada perlakuan $50 \%$ tepung kedelai: $50 \%$ tepung terigu. Ada kecenderungan semakin tinggi rasio penggunaan tepung terigu, semakin tinggi kandungan karbohidrat.

Dan secara umum tidak ada interaksi perlakuan antar varietas dan proporsi substitusi tepung kedelai, tetapi kandungan karbohidrat tertinggi $62.61 \%$ diperoleh pada perlakuan $100 \%$ menggunakan tepung terigu untuk semua varietas dan terendah $40.25 \%$ pada perlakuan varietas Detap 1 dengan penggunaan 50\% tepung kedelai: 50 tepung terigu. Semakin besar proporsi substitusi tepung kedelai ditambahkan pada pembuatan mie, maka kandungan karbohidrat juga semakin rendah.

Kandungan karbohidrat yang terkandung pada mie yang dihasilkan dengan subtitusi penggunaan tepung kedelai dan tepung terigu berkisar $40.25-62.51 \%$ memenuhi standar mutu mie basah (SNI 01-2987-1992) yaitu minumum $3 \%$.

\section{Uji Organoleptik Mie Kedelai}

Mutu suatu produk selain ditentukan dari komponen gizinya, juga sangat tergantung pada faktor cita rasa, warna dan tekstur. Hasil uji statistik produk mie hasil substitusi tepung terigu dan tepung kedelai terhadap uji organoleptik meliputi penilaian warna, aroma, rasa, tekstur dan penilaian secara keseluruhan dapat dilihat pada tabel berikut.

Tabel 1.Daya terima panelis Terhadap Warna, Aroma, Rasa dan keseluruhan

\begin{tabular}{|c|c|c|c|c|c|}
\hline Substitusi tepung kedelai & Warna & Aroma & Rasa & Tekstur & Keseluruhan \\
\hline $0 \%$ & $3.7 \mathrm{ab}$ & $3.7 \quad \mathrm{a}$ & $4.0 \mathrm{a}$ & 4.0 & 4.0 \\
\hline $20 \%$ & 3.8 & 3.8 & 3.8 & 3.7 & 4.0 \\
\hline $40 \%$ & $3.5 \mathrm{ab}$ & 3.5 & 3.2 & 3.4 & 3.6 \\
\hline $50 \%$ & $3.3 \mathrm{a}$ & 3.1 & $3.0 \mathrm{~b}$ & 2.8 & 3.1 \\
\hline
\end{tabular}

Angka-angka pada kolom yang sama yang diikuti huruf yang sama menunjukkan nilai yang tidak berbeda nyata pada taraf uji $5 \%$.

\section{Warna}

Warna merupakan salah satu kunci agar konsumen mau mencoba dan menjadi daya tarik tersendiri bagi makanan yang diproduksi. Secara umum warna mie yang ada dipasaran ada yang berwarna putih dan kuning. Mie yang dihasilkan dengan substitusi tepung kedelai berwarna putih kekuning-kuningan. Hasil uji statistik terhadap parameter warna menunjukkan bahwa tidak berpengaruh nyata antar perlakuan tetapi semakin besar proporsi substitusi tepung kedelai kesukaan panelis semakin berkurang. Hal ini karena semakin banyak penambahan tepung kedelai menyebabkan warna mie menjadi agak kekuningan. Warna kekuningan ini disebabkan warna dari tepung kedelai yang berwarna agak kekuningan. Berdasarkan penilaian dari segi warna, untuk semua perlakuan masih dapat diterima oleh panelis dengan skore rata-rata $3.3-3.8$ termasuk dalam kategori suka dan skore tertinggi pada perlakuan dengan substitusi $20 \%$ tepung kedelai.

\section{Aroma}

Aroma merupakan salah satu parameter kunci dalam uji organolpetik, karena aroma terhadap produk akan menentukan penilaian citarasa konsumen. Hasil uji statistik terhadap parameter aroma menunjukkan bahwa perlakuan dengan substitusi $50 \%$ tepung kedelai berbeda nyata dengan perlakuan lainnya. Dan semakin tinggi proporsi subtitusi tepung kedelai semakin rendah nilai skore kesukaan panelis. Hal ini 
disebabkan semakin besar proporsi penggunaan tepung kedelai bau langau dari tepung kedelai semakin terasa. Namun berdasarkan hasil penilaian terhadap aroma, untuk semua perlakuan berada dalam kisaran suka sampai agak suka yaitu 2.1 3.8. Skore tertinggi diperoleh pada perlakuan dengan substitusi $20 \%$ tepung kedelai.

\section{Tesktur}

Tekstur makanan memiliki peranan penting dalam mempengaruhi penerimaan sesorang terhadap suatu produk. Fitriyani, (2011) dan Widyaningsih dan Murtini (2006), menyatakan mie yang baik mempunyai tekstur kenyal dan tidak mudah putus. Hasil uji statistik menunjukkan bahwa penggunaan 100 tepung terigu atau tanpa penggunan tepung kedelai dalam pembuatan mie memberi nilai skore tertinggi yaitu 4.0, dan tidak berpengaruh nyata dengan perlakuan substitusi tepung kedelai sampai tingkat $20 \%$. Akan tetapi berpengaruh nyata dengan perlakuan substitusi tepung kedelai $40-50 \%$.

Berdasarkan hasil penilaian panelis terhadap tekstur, skore berkisar antara $2.8-4.0$ yang berarti agak suka sampai sangat suka. Semakin besar proporsi penggunaan tepung kedelai, tekstur mie yang dihasilkan semakin tidak disenangi panelis.
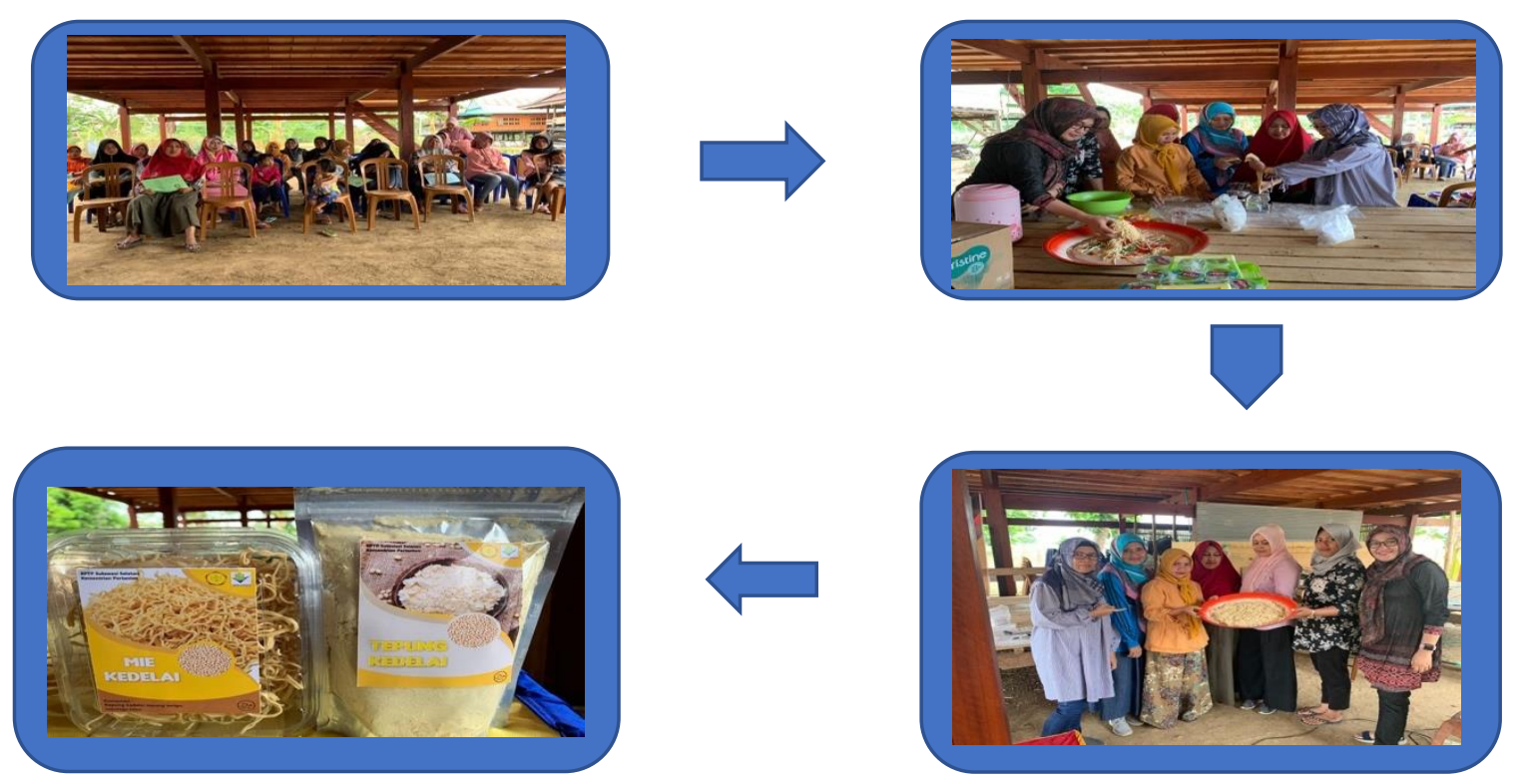

Gambar 1. Sosialisasi produk

Diterbitkan Oleh,

Unit Penelitian dan Pengabdian Masyarakat, Politeknik Pembangunan Pertanian Gowa

http://ejournal.polbangtan-gowa.ac.id 


\section{Sosialisasi Produk}

Sosialisasi produk (Gambar 1) dilakukan didaerah sentra pengembangan kedelai, di kelompok tani Sipatuo, Kelurahan Tancung, Kecamatan Tanasitolo, Kabupaten Wajo. Acara sosialisasi dihadiri oleh warga yang berada di sekitar lokasi tersebut, dengan jumlah peserta \pm 25 orang.

Pada acara sosialisasi dilakukan demonstrasi pembuatan tepung dan pembuatan mie kedelai dengan perlakuan yang disenangi panelis secara umum berdasarkan hasil uji organoleptik, yaitu substitusi $20 \%$ tepung kedelai.

Respon masyarakat dengan adanya kegiatan ini sangat baik, karena mereka baru mengenal adanya produk tersebut, serta teknologi pembuatannya mudah diterapkan ditingkat rumah tangga.

\section{KESIMPULAN}

1. Perlakuan dengan substitusi tepung kedelai sebesar 20-40\% dalam pembuatan adonan dapat dicetak menjadi mie dengan kualitas baik.

2. SNI 01-2987-1992 mie basah yang dihasilkan telah memenuhi standar, yaitu kadar air 15.82$21.33 \%$ (SNI 20-35\%), kadar abu 1.03-1.97\% (SNI minimal 3\%), kadar protein 11.86$25.42 \%$ (minimum 3\%), dan karbohidrat 40.25 $-62.51 \%$ (minimum 3\%).

\section{DAFTAR PUSTAKA}

Badan Penelitian dan Pengembangan Pertanian. Mutu Kedelai Nasional Lebih baik dari kedelai Impor. Jakarta: Siaran Pers, 2008.

Badan Standarisasi Nasional. 2015. Mie Basah. SNI-01-2987-2015. Badan Standarsasi Nasional, Jakarta .

Cahyadi, W. 2007. Teknologi dan Khasiat Kedelai. Bumi Aksara. Jakarta.

Fitriyani, R., 2011. Pembuatan Mie Basah. Berkarya-prestasi. Blogspot.com. Diakses

Gaman, P.M. dan Sherington, K.B. 1994 Ilmu Pangan. Gajah Mada. University Press. Yogyakarta. 317 halaman

Gozali, M., 2015. Karakteristik Tepung Kedelai dari jenis impor dan lokal (Varietas
Anjasmoro dan Baluran) dengan perlakuan perebusan dan tanpa perebusan. Teknologi Hasil Pertanian, Fakultas Teknologi Pertanian, Universitas Jember. Skripsi.

Hadininigsih, N. 1999. Pemanfaatan tepung jagung sebagai bahan pensubstitusi terigu dalam pembuatan produk mie kering yang difortifikasi dengan tepung bayam. Skripsi Fakultas Teknologi Pangan. Institut Pertanian Bogor.

Hoseney, R. C., (1998), Principles of Cereal Science and Technology, 2nd ed., American Association of Cereal Chemists, Inc. St. Paul, Minnesota

Juniawati. 2003. Optimasi Proses Pengolahan Mie Jagung Instan Berdasarkan Preferensi Konsumen. Skripsi. Institut Pertanian Bogor. Bogor.

Khomsan A.,2002. Susut Gizi Akibat proses pemasakan. Diakses pada tgl 14 April 2015 dari http:// www. kompas.com /kesehatan/ news/ 0204/ 23/ 015943.)

Layuk., P., M. Lintang., G.H. Yoseph., M.M. Rumokoi., R. Novarianto., dan J.G. Kindangen. 2002. Pasca Panen dan Pengolahan Kedelai. Balai Pengkajian Teknologi Pertanian Sulawesi Utara.

Manley D., 2000. Technology of Biscuits, Crackers and Cookies. Third Edition. Woodhead Publishing Limited. England.

Millah, S., dan Gemala Anjani. 2017. Substitusi Tepung Kedelai hitam pada Mie Basah untuk Penderita Hiperkolesterolemia. Jounal of Nutrition College. Vol. 6, No 2.

Muhajir., 2007. Peningkatan Gizi Mie instant dari campuran tepung terigu dan tepung ubi jalar Mlalui penambahan tepung tempe dan tepung ikan. Fakultas Pertanian. Universitas Sumatra Utara.

Nasution., E.Z., 2005. Pembuatan mie kering dari tepung terigu dengan tepung rumput laut yang difortifikasi dengan kacang kedelai. Jurnal Sains Kimia. Vol. 9, No. 2.

Nurmala, T dan A.W. Irawan. 2007. Pangan Alternatif Berbasis Serealia Minor. Giratuna. Bandung.,

Prasetya, A. 2018. Fortifikasi Bji Buah Nangka (Artocarpus heterophyyllus) dan Tulang Ikan Pepetek (Leiognathus sp.) Sebagai

Diterbitkan Oleh, 
Bahan Olahan Mie Basah.Universitas Islam Negeri Raden Intan, Lampung. Skripsi.

Rani H., Zulfahmi dan Yatim R. Widodo. 2013. Optimasi Proses Pembuatan Bubuk (Tepung) Kedelai. Jurnal Penelitian Pertanian Terapan. Vol. 13, No. 3. ISSN 1410 - 5020.

Salim, E. 2012. Kiat Cerdas Wirausaha Aneka Olahan Kedelai. Andi Offset.

Sudarmadji, S., Haryono, B dan Suhadi. 1989. Analisa Bahan Makanan dan Pertanian. Edisi I. Yogyakarta: Penerbit Liberti.

Subarna 1992. Baking Technology. Pelatihan Singkat Prinsip-Prinsip Teknologi bagi
Food Inspector. PAU Pangan dan Gizi, IPB, Bogor.

Virgo, S. D., 2007. Pengaruh Pemberian Tepung Kedelai Terhadap Daya Simpan Nugget Ayam Ras Afkir. Fakultas Peternakan Universitas Andalas, Padang.

Widyaningsih dan Murtini, 2006. Alternatif Penggunaan Formalin pada ProdukPangan. Trubus Agrisarana. Surabaya.

Winarno, F.G. dan T.S. Rahayu, 1994. Bahan Makanan Tambahan Untuk Makanan dan Kontaminan. Pustaka Sinar Harapan. Jakarta. 